\title{
Effect of dispersants of multi-walled carbon nanotubes on cellular uptake and biological
} responses

\author{
Hisao Haniu' \\ Naoto Saito ${ }^{2}$ \\ Yoshikazu Matsuda ${ }^{3}$ \\ Yoong-Ahm Kim ${ }^{4}$ \\ Ki Chul Park' \\ Tamotsu Tsukahara ${ }^{5}$ \\ Yuki Usui ${ }^{6}$ \\ Kaoru Aoki ${ }^{7}$ \\ Masayuki Shimizu ${ }^{7}$ \\ Nobuhide Ogihara ${ }^{7}$ \\ Kazuo Hara ${ }^{7}$ \\ Seiji Takanashi ${ }^{7}$ \\ Masanori Okamoto ${ }^{7}$ \\ Norio Ishigaki ${ }^{7}$ \\ Koichi Nakamura ${ }^{7}$ \\ Hiroyuki Kato ${ }^{7}$ \\ 'Institute of Carbon Science and \\ Technology, Shinshu University, \\ Matsumoto, Nagano, Japan; ${ }^{2}$ Department \\ of Applied Physical Therapy, Shinshu \\ University School of Health Sciences, \\ Matsumoto, Nagano, Japan; ${ }^{3}$ Clinical \\ Pharmacology Educational Center, Nihon \\ Pharmaceutical University, Ina-machi, \\ Saitama, Japan; ${ }^{4}$ Faculty of Engineering, \\ Shinshu University, Nagano-shi, Nagano, \\ Japan; ${ }^{5}$ Department of Integrative \\ Physiology and Bio-System Control, \\ Shinshu University School of Medicine, \\ Matsumoto-shi, Nagano, Japan; ${ }^{6}$ Research \\ Center for Exotic Nanocarbons, Shinshu \\ University, Matsumoto, Nagano, Japan; \\ ${ }^{7}$ Department of Orthopedic Surgery, \\ Shinshu University School of Medicine, \\ Matsumoto, Nagano, Japan
}

Correspondence: Hisao Haniu Institute of Carbon Science and Technology, Shinshu University, 3-I-I Asahi,

Matsumoto, Nagano 390-8621, Japan

Tel +8I 263372659

Fax +8I 263358844

Email hhaniu@shinshu-u.ac.jp
This article was published in the following Dove Press journal:

International Journal of Nanomedicine

8 December 2011

Number of times this article has been viewed

\begin{abstract}
Although there have been many reports about the cytotoxicity of multi-walled carbon nanotubes (MWCNTs), the results are still controversial. To investigate one possible reason, the authors investigated the influence of MWCNT dispersants on cellular uptake and cytotoxicity. Cytotoxicity was examined (measured by alamarBlue ${ }^{\circledR}$ assay), as well as intracellular MWCNT concentration and cytokine secretion (measured by flow cytometry) in human bronchial epithelial cells (BEAS-2B) exposed to a type of highly purified MWCNT vapor grown carbon fiber (VGCF ${ }^{\circledR}$, Shōwa Denkō Kabushiki-gaisha, Tokyo, Japan) in three different dispersants (gelatin, carboxylmethyl cellulose, and 1,2-dipalmitoyl-sn-glycero-3-phosphocholine). The authors also researched the relationship between the intracellular concentration of MWCNTs and cytotoxicity by using two cell lines, BEAS-2B and MESO-1 human malignant pleural mesothelioma cells. The intracellular concentration of VGCF was different for each of the three dispersants, and the levels of cytotoxicity and inflammatory response were correlated with the intracellular concentration of VGCF. A relationship between the intracellular concentration of VGCF and cytotoxic effects was observed in both cell lines. The results indicate that dispersants affect VGCF uptake into cells and that cytotoxicity depends on the intracellular concentration of VGCF, not on the exposed dosage. Thus, toxicity appears to depend on exposure time, even at low VGCF concentrations, because VGCF is biopersistent.
\end{abstract}

Keywords: multi-walled carbon nanotube, cytotoxicity, intracellular concentration, dispersant, cytokine secretion

\section{Introduction}

Because of their unique properties, multi-walled carbon nanotubes (MWCNTs) have applications in a wide variety of industries. Currently, hundreds of tons of MWCNTs are produced around the world. ${ }^{1}$ Because carbon nanotubes (CNTs) have an asbestoslike shape, their safety has been a hot topic. In vivo studies have shown that the intrapulmonary administration of CNTs causes transient inflammatory responses and the development of granuloma tissue and fibrosis..$^{2-4}$ In 2008, Takagi et $\mathrm{al}^{5}$ and Poland et $\mathrm{al}^{6}$ reported that mice intraperitoneally injected with MWCNTs exhibited the same toxicological changes that are seen in mice exposed to asbestos. However, studies of inhalation exposure to MWCNTs have not been performed in rats. ${ }^{7,8}$

In vitro experiments have shown that CNTs can induce cytokine production or an oxidative stress reaction in lung epithelial cells, keratinocytes, and immune cells, such as macrophages. ${ }^{9-13}$ However, other studies have shown CNTs to cause no significant biological response. ${ }^{14-17}$ The conflicting results may result from differences in the type of CNTs used (diameter, length, single-walled, or multi-walled), exposure concentration, exposure period, impurities, and dispersion medium. Davoren et $\mathrm{al}^{18}$ and Herzog et al ${ }^{19}$ 
separately studied the cytotoxic effects of $50 \mu \mathrm{g} / \mathrm{mL}$ singlewalled CNTs (SWCNTs) in different dispersion conditions on A549 lung epithelial cells; the results of these two studies indicated that SWCNTs dispersed in medium containing serum did not exhibit cytotoxicity and that SWCNTs dispersed in medium containing serum and the dispersant 1,2-dipalmitoylsn-glycero-3-phosphocholine did exhibit cytotoxicity. However, although their experiments clarified the influence of the presence of a dispersant, neither study demonstrated differences between various dispersants. Moreover, the exact relationship between the dispersant and cytotoxicity was not clarified. Recently, Kim et $\mathrm{al}^{20}$ investigated the dispersion of CNTs in five dispersants and the toxicity of the dispersants but did not examine whether the toxicity of CNTs changed in different dispersants. Dispersant changes the degree of CNT dispersion, and it is possible that this contributes to cytotoxicity.

In the present study, we compared the cytotoxic responses of bronchial epithelial cells to MWCNTs in three different dispersants. We found that dispersants had a crucial effect on MWCNT uptake and that the amount of MWCNTs incorporated by the cells is an important factor in cytotoxicity. We also confirmed the universality of the results through experiments with malignant mesothelioma cells. We did not pay attention to whether dispersant contributes to CNT recognition and/or uptake by cells.

\section{Materials and methods}

\section{Multi-walled carbon nanotubes}

We used a commercial MWCNT material, vapor grown carbon fiber $\left(V_{G C F}{ }^{\circledR}\right.$, Shōwa Denkō Kabushiki-gaisha, Tokyo, Japan), that is manufactured by a chemical vapor deposition method. The mean diameter and length of VGCF are reported by the company to be $150 \mathrm{~nm}$ and $8 \mu \mathrm{m}$, respectively. The carbon purity is approximately $99.9 \%$, and the amount of the entrapped metal obtained by an inductively coupled plasma mass spectrometer is less than $20 \mathrm{ppm}$. Sterilization was performed at $121^{\circ} \mathrm{C}$ for 15 minutes in an autoclave.
Three dispersants were prepared. Gelatin (Nacalai Tesque Inc, Kyoto, Japan) and carboxylmethyl cellulose (CMC; Wako Pure Chemical Industries Ltd, Osaka, Japan) were dissolved in phosphate buffered saline (PBS) and adjusted to a concentration of $0.1 \%$, and 1,2-dipalmitoylsn-glycero-3-phosphocholine (DPPC; Sigma-Aldrich ${ }^{\circledR}$ Corp, St Louis, MO, USA) was dissolved in PBS containing $1 \mathrm{mg} / \mathrm{mL}$ glucose and $0.6 \mathrm{mg} / \mathrm{mL}$ bovine serum albumin $(0.01 \mathrm{mg} / \mathrm{mL}) .{ }^{21} \mathrm{VGCF}(10 \mathrm{mg} / \mathrm{mL})$ was suspended in each of these three dispersants, vortexed for 1 minute, and sonicated for 30 minutes. The basic properties of VGCF dispersed in the three different dispersants were measured ${ }^{22,23}$ and are summarized in Table 1 and Supplementary 1-6. Dispersed VGCF in each dispersant was added to cell culture medium at $1 / 100$ volume in the following experiments.

\section{Cell culture}

The human bronchial epithelial cell line (BEAS-2B) was purchased from the American Type Culture Collection (Manassas, VA, USA). The ACC-MESO-1 human malignant pleural mesothelioma cell line (MESO-1) was purchased from Riken BioResource Center (Ibaraki, Japan). ${ }^{24}$ BEAS-2B cells were cultured in Ham's nutrient mixture F-12 with 10\% fetal bovine serum. MESO-1 cells were cultured in RPMI 1640 supplemented with $10 \%$ fetal bovine serum. Both cell lines were cultured at $37^{\circ} \mathrm{C}$ in a $5 \% \mathrm{CO}_{2}$ humidified incubator and passaged twice in a week. For each study, $2 \times 10^{5} \mathrm{cells} / \mathrm{cm}^{2}$ of the cells were plated to each plate or dish and cultured for 24 hours, until the exponential growth phase.

\section{alamarBlue ${ }^{\circledR}$ assay}

To determine the viability of cells exposed to various concentrations of VGCF, we performed an alamarBlue ${ }^{\circledR}$ (AB) assay (Invitrogen Corp, Carlsbad, CA, USA) according to the manufacturer's instructions after having confirmed that VGCF amounts less than $50 \mu \mathrm{g} / \mathrm{mL}$ do not influence the $\mathrm{AB}$ assay. Cells in a 96-well plate were incubated for

Table I Basic properties of vapor grown carbon fiber $\left(\mathrm{VGCF}^{\circledR}\right)$ in different dispersants

\begin{tabular}{lllll}
\hline & VGCF in gelatin & VGCF in CMC & VGCF in DPPC & Testing method \\
\hline Diameter $(\mathrm{nm})$ & $80-130$ & $80-130$ & $80-130$ & FE-SEM \\
Length $(\mu \mathrm{m})$ & $7-10$ & $7-10$ & $7-10$ & FE-SEM \\
$\mathrm{d}_{002}(\AA)$ & 3.385 & 3.385 & 3.385 & X-ray diffraction \\
$\mathrm{R}$ value $\left(I_{\mathrm{d}} /\right)^{\mathrm{a}}$ & 0.088 & 0.089 & 0.104 & Raman spectroscopy $(514 \mathrm{~nm})$ \\
Specific surface area $\left(\mathrm{m}^{2} / \mathrm{g}\right)$ & 15 & 17 & 17 & $\mathrm{~N}_{2}$ adsorption \\
Real density $\left(\mathrm{g} / \mathrm{cm}^{3}\right)$ & 2.1 & 2.1 & 2.1 & Pycnometer \\
Zeta potential $(\mathrm{mV})$ & $1.18 \pm 1.66$ & $1.22 \pm 1.72$ & $1.09 \pm 0.22$ & Particle sizing and zeta potential analyzer \\
Agglomerate diameter $(\mathrm{nm})$ & 1,442 & 3,201 & 2,336 & Particle sizing and zeta potential analyzer \\
\hline
\end{tabular}

Notes: ${ }^{a} \mathrm{R}$ refers to the intensity of $\mathrm{D}$ band over the intensity of $\mathrm{G}$ band; ${ }^{\mathrm{b}}$ phase-analysis light scattering method; 'dynamic light scattering technique.

Abbreviations: CMC, carboxylmethyl cellulose; DPPC, I,2-dipalmitoylsn-glycero-3-phosphocholine; FE-SEM, field emission scanning electron microscope. 
24 hours at $37^{\circ} \mathrm{C}$ in culture medium containing VGCF or dispersant control (DC). Viable cells metabolized the dye, resulting in an increase of fluorescence by excitation/emission at $550 / 600 \mathrm{~nm}$ as measured by a fluorescence multiplate reader (PowerScan 4; DS Pharma Biomedical, Osaka, Japan). Cytotoxic activity was calculated as follows: percent cytotoxicity $=100 \times$ experimental value/DC value. Test media were assayed eight times for each treatment condition.

\section{Imaging VGCF uptake}

BEAS-2B cells in a 12-well plate were incubated with or without VGCF in various DC for 24 hours in $5 \% \mathrm{CO}_{2}$. Cell images and movies were obtained using an IX71 light microscope (Olympus, Tokyo, Japan) without washing the cells, thereby allowing observation of VGCF movement in the culture medium. To visualize the volume and localization of internalized VGCF, BEAS-2B and MESO-1 cells were incubated with VGCF in a glass-bottomed dish for 24 hours, and the cell nucleus was stained with Hoechst 33342 ( $1 \mu \mathrm{g} / \mathrm{mL}$; Dojindo Laboratories, Kumamoto, Japan) for 30 minutes. The dish was placed on the stage of a LSM 510 NLO laser-scanning confocal microscope (Carl Zeiss, Jena, Germany) using a $\times 20$ objective and imaged with a $405 \mathrm{~nm}$ blue diode laser for excitation and a $420 \mathrm{~nm}$ longpass filter to capture the blue emission.

\section{Cytokine measurement}

Cytokines in the culture supernatant were measured with a cytometric bead array flex set system (BD Biosciences, San Jose, CA, USA), according to the manufacturer's protocol. Briefly, BEAS-2B cells in a 24 -well plate were exposed to $10 \mu \mathrm{g} / \mathrm{mL}$ of VGCF in various DC for 24 hours; then, cytokine capture beads (for TNF- $\alpha$, IL-1 $\beta$, IL-6, and IL-8) were added to the samples or cytokine standards $(20 \sim 5,000 \mathrm{pg} / \mathrm{mL})$ in flow cytometry tubes. The mixtures were vortexed, and antibody for fluorescence detection was added to each tube. The samples were then incubated at room temperature for 2 hours. Following incubation, the beads were washed once and resuspended prior to reading with a FACSCalibur ${ }^{\mathrm{TM}}$ apparatus (BD Biosciences). Test media were assayed in triplicate for each treatment condition.

\section{Assessment of VGCF uptake by flow cytometry}

The assessment of VGCF uptake was determined by flow cytometry, using the method of Al-Jamal and Kostarelos ${ }^{25}$ with slight modifications. Briefly, the cells were grown in 24-well plates that were incubated for 1 hour and 24 hours at $37^{\circ} \mathrm{C}$ in the presence or absence of VGCF. The cells were washed with PBS to remove unbound VGCF, harvested with trypsin, and centrifuged at $400 \times \mathrm{g}$ for 5 minutes. The precipitated cells were suspended in PBS containing 10\% fetal bovine serum and filtered thorough nylon mesh $(67 \mu \mathrm{m}$ pore size) to remove the agglutinated VGCF on the surface. Side scatter (SSC) in a light-scattering analysis was immediately measured up to 10,000 events using FACSCalibur ${ }^{\mathrm{TM}}$. Test media were assayed in triplicate for each treatment condition.

\section{Assessment of cell size}

Untreated BEAS-2B and MESO-1 cells in a $6 \mathrm{~cm}$ culture dish were washed once with PBS and then harvested with trypsin. The trypsinized cells were suspended in PBS, and the cell size was assayed using Multisizer ${ }^{\mathrm{TM}} 4$ Coulter Counter $^{\circledR}$ (Beckman Coulter Inc, Brea, CA) by counting 10,000 cells.

\section{Statistical analysis}

Data are presented as mean \pm standard error $(\mathrm{SE})$, the Student's $t$-test was used for the data analysis and $P<0.05$ was considered statistically significant.

\section{Results}

\section{Influence of dispersion medium}

The effect of VGCF $(10 \mu \mathrm{g} / \mathrm{mL})$ in three different dispersants on BEAS-2B cell viability was measured using alamarBlue ${ }^{\circledR}$ reagent (Figure 1). VGCF dispersed in gelatin decreased cell viability by $38 \%$, and VGCF dispersed in DPPC decreased cell viability by $83 \%$. In contrast, VGCF

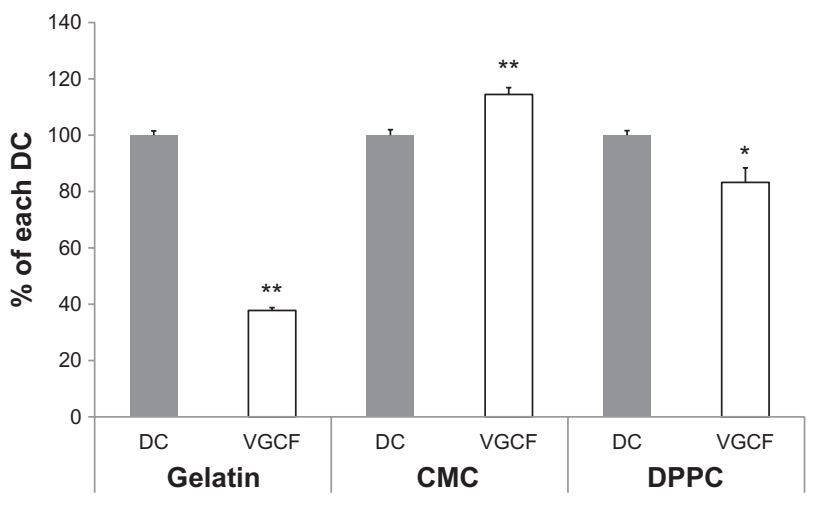

Figure I Cell viability in different types of dispersion medium. An alamarBlue ${ }^{\circledR}$ assay indicates the viability of BEAS-2B cells incubated with $10 \mu \mathrm{g} / \mathrm{mL}$ of VGCF in different types of dispersion medium for 24 hours.

Notes: The data represent the relative ratio of cell viability in DC with VGCF to the cell viability in DC without VGCF. Mean \pm SE $n=8$, ${ }^{*} P<0.05$, ${ }^{* *} P<0.001$.

Abbreviations: CMC, carboxylmethyl cellulose; DC, dispersant control; DPPC, I,2-dipalmitoylsn-glycero-3-phosphocholine; SE, standard error; VGCF, vapor grown carbon fiber $\left(\mathrm{VGCF}^{\circledR}\right)$. 
dispersed in CMC increased cell viability compared with the control (114\%).

VGCF was recorded in each dispersant at 1 hour (Movie S1-S3). Large amounts of VGCF had already settled on the bottom of the culture dish. VGCF in gelatin and in CMC showed movement resembling Brownian motion. Optical microscope images of cells treated with VGCF in the different dispersants at 24 hours are shown in Figure 2. Intracellular aggregation of VGCF is apparent when gelatin or DPPC is used as the dispersant. However, VGCF in CMC was well dispersed, compared with VGCF in gelatin or DPPC, and intracellular uptake was not seen for VGCF in CMC until 24 hours (Movie S4).

We subsequently analyzed the light scattering during flow cytometry to quantify the amount of intracellular
VGCF (Figure 3B). Before flow cytometry, we confirmed that VGCF was not adhered to the cells; rather, most of the VGCF was internalized into the cells that were harvested by trypsin and filtered through the nylon mesh (Figure 3A). After 1-hour exposure to VGCF, the SSC was significantly increased in all dispersants as compared with the dispersant-only control. The relative rates compared with the control were 1.65 in gelatin and less than 1.1 in CMC or DPPC (Figure 3C). In contrast, after 24 hours, the relative rates were 2.40 and 1.88 in gelatin and DPPC, respectively, but there was almost no change for CMC (1.05). These data show that VGCF in CMC was not internalized by the cells.

We also examined the influence of intracellular VGCF on cytokine secretion in BEAS-2B cells. BEAS-2B cells exposed to VGCF in both DPPC and gelatin exhibited significantly
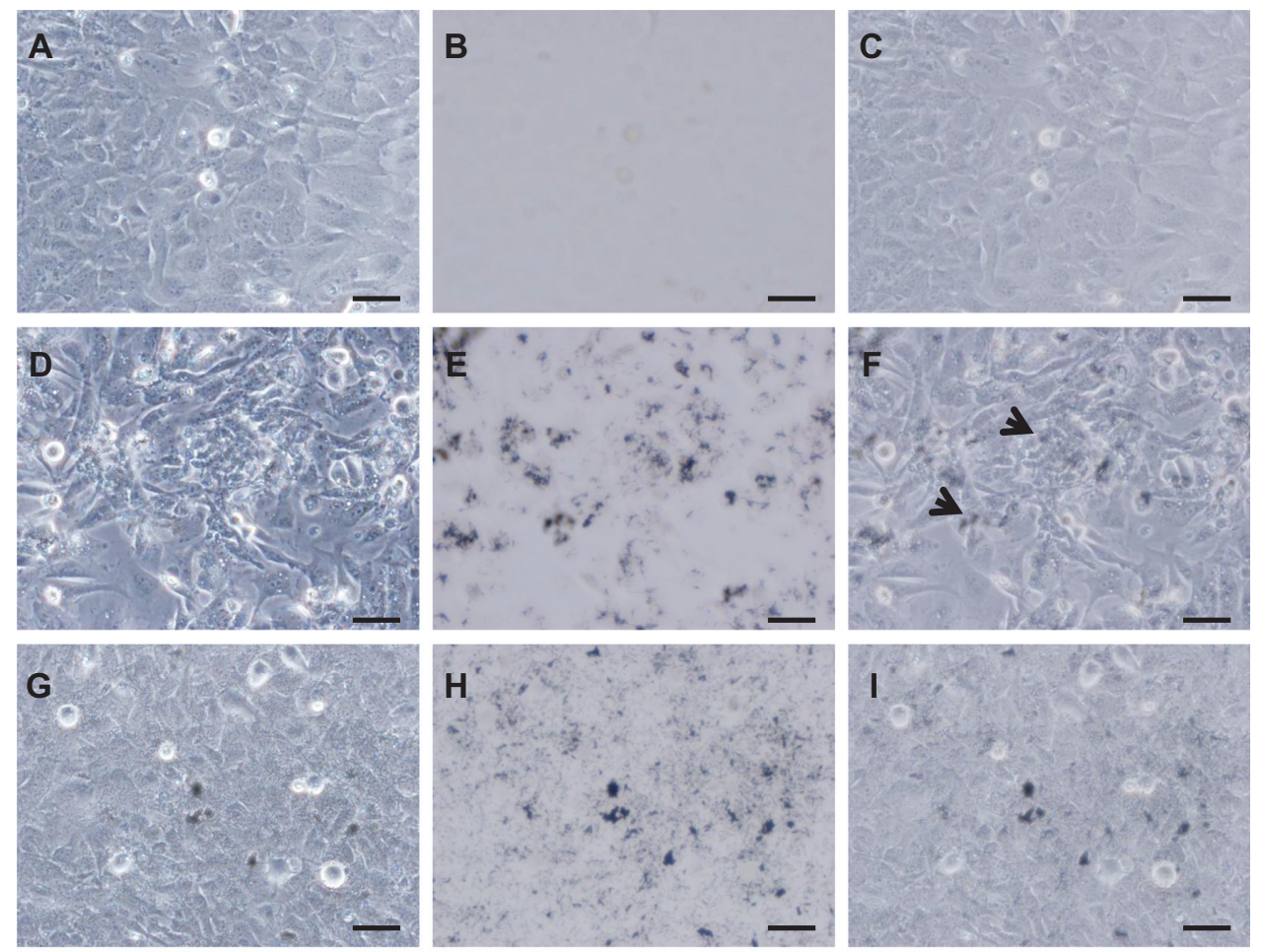

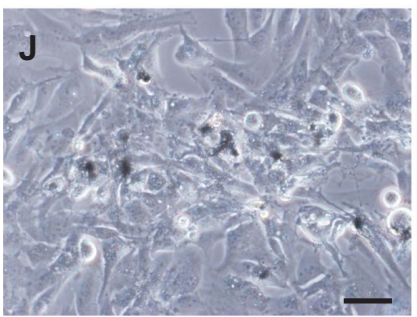

Phase contrast

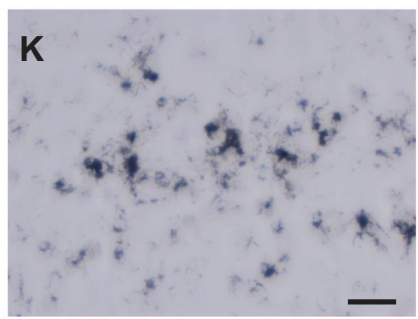

Bright field

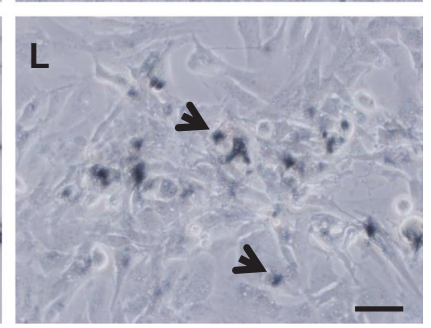

Merged

Figure 2 VGCF uptake in different types of dispersion medium. BEAS-2B cells incubated with or without $10 \mu g / \mathrm{mL}$ of VGCF in different types of dispersion medium for 24 hours. A-C, without VGCF; D-F, with $10 \mu \mathrm{g} / \mathrm{mL}$ of VGCF in gelatin; G-I, with $10 \mu \mathrm{g} / \mathrm{mL}$ of VGCF in CMC; J-L, with $10 \mu \mathrm{g} / \mathrm{mL}$ of VGCF in DPPC.

Notes: Arrow indicates cell with endocytosed VGCF. Bar indicates $50 \mu \mathrm{m}$. Phase contrast images for cell observation (A, D, G, J), bright field images for VGCF observation (B, E, H, K), and combined images (C, F, I, L) are shown.

Abbreviations: CMC, carboxylmethyl cellulose; VGCF, vapor grown carbon fiber (VGCF ${ }^{\circledR}$ ); DPPC, I,2-dipalmitoyl-sn-glycero-3-phosphocholine. 
A
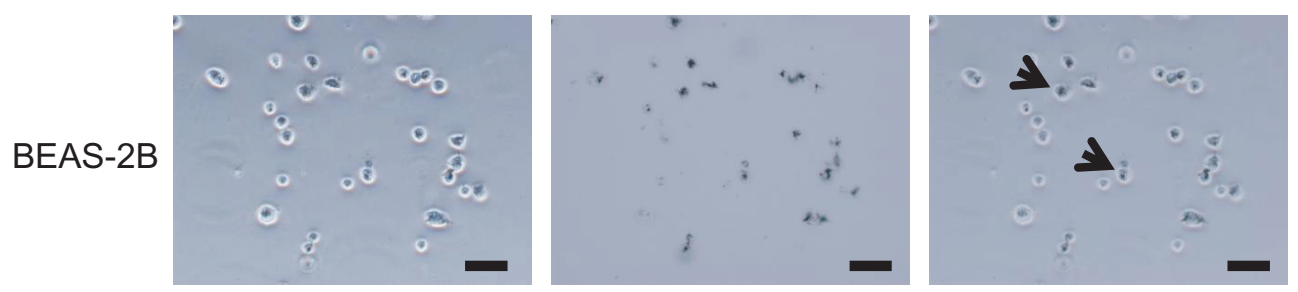

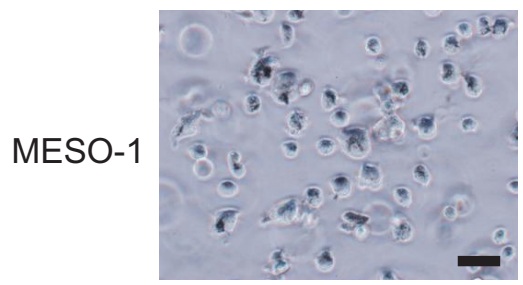

Phase contrast

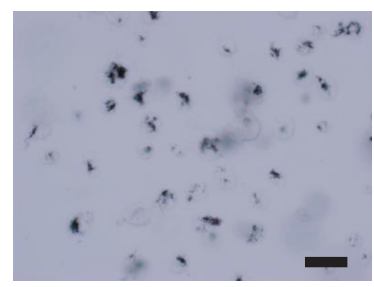

Bright field

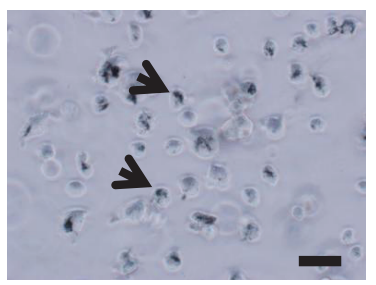

Merged
B

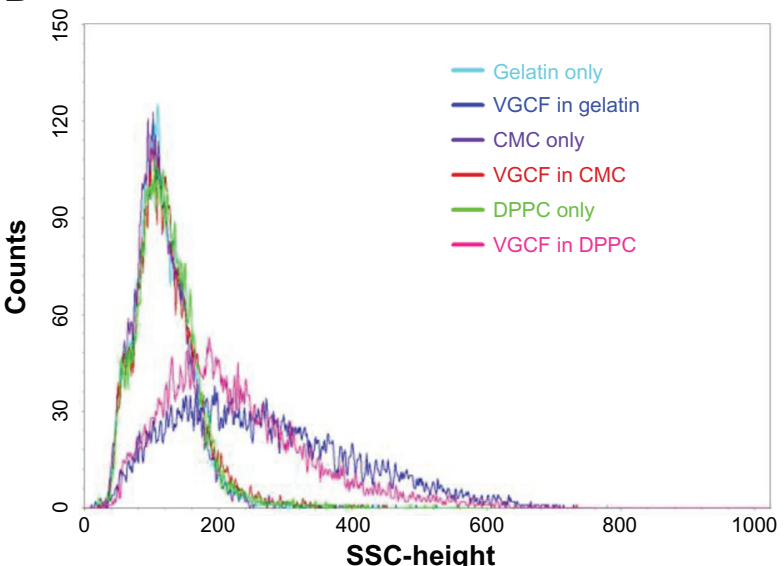

SSC-height

C

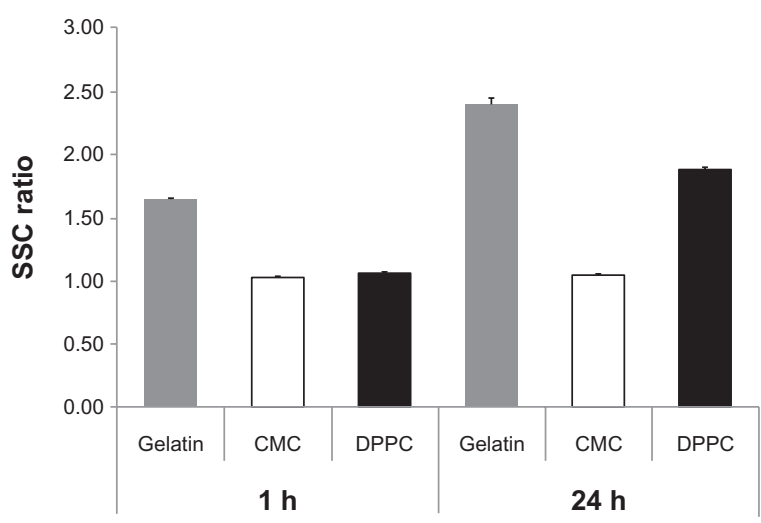

\begin{tabular}{|c|c|c|c|c|c|c|}
\hline & Gelatin & $\begin{array}{c}\text { VGCF in } \\
\text { gelatin }\end{array}$ & CMC & $\begin{array}{c}\text { VGCF in } \\
\text { CMC }\end{array}$ & DPPC & $\begin{array}{c}\text { VGCF in } \\
\text { CMC }\end{array}$ \\
\hline $1 \mathrm{~h}$ & $124.5 \pm 0.6$ & $205.5 \pm 1.8^{\star \star}$ & $124.9 \pm 0.2$ & $128.0 \pm 0.3^{\star \star}$ & $125.7 \pm 0.6$ & $133.8 \pm 0.6^{\star \star}$ \\
\hline $24 \mathrm{~h}$ & $114.2 \pm 0.6$ & $274.4 \pm 5.7^{\star}$ & $114.5 \pm 0.7$ & $120.3 \pm 0.4^{\star \star}$ & $116.6 \pm 2.5$ & $219.8 \pm 1.2^{\star \star}$ \\
\hline
\end{tabular}

Figure 3 Quantification of VGCF uptake in different types of dispersion medium. (A) Trypsinized BEAS-2B and MESO-I cells before flow cytometry. BEAS-2B cells exposed to $5 \mu \mathrm{g} / \mathrm{mL}$ of VGCF. MESO-I cells exposed to $10 \mu \mathrm{g} / \mathrm{mL}$ of VGCF. Arrow indicates cell with endocytosed VGCF. Bar indicates $50 \mu \mathrm{m}$. (B) A univariate scatter histogram showing the cell counts vs sideward scattering ${ }^{46}$ for cells incubated with $10 \mu \mathrm{g} / \mathrm{mL}$ of VGCF in different types of dispersion medium for 24 hours. Each sample was I0,000 cells. Table shows the SSC value after I hour and 24 hours (mean \pm SE $n=3, * P<0.0$, **P $<0.00$ I. (C) The SSC ratio was calculated as the VGCF value divided by the DC value and indicates the relative VGCF volume.

Abbreviations: CMC, carboxylmethyl cellulose; DC, dispersant control; DPPC, I,2-dipalmitoylsn-glycero-3-phosphocholine; SE, standard error; SSC, side scatter; VGCF, vapor grown carbon fiber $\left(\mathrm{VGCF}^{\circledR}\right)$.

increased amounts of IL-6 and IL-8 secretion that were correlated with the intracellular VGCF concentration. In contrast, cells exposed to VGCF in CMC did not show any increase in secretion of either IL-6 or IL-8 (Figure 4A, B). Other cytokines, such as TNF- $\alpha$ and IL-1 $\beta$, were not detected under any conditions.

\section{Influence of internalized VGCF}

Next, we evaluated the relationship between the intracellular concentration of VGCF and the viability of BEAS-2B and MESO-1 cells. In both cell lines, we observed a decrease in cell viability in a VGCF-dependent manner (Figure 5).
However, the half-maximal inhibitory concentration $\left(\mathrm{IC}_{50}\right)$ values differed; the decreased viability in BEAS-2B cells $\left(\mathrm{IC}_{50}=7 \mu \mathrm{g} / \mathrm{mL}\right)$ was greater than that in MESO-1 cells $\left(\mathrm{IC}_{50}=17 \mu \mathrm{g} / \mathrm{mL}\right)$.

In both cell lines, the relative uptake increased in a concentration-dependent manner (Figure 5). The slopes of the increase in VGCF uptake were different, with BEAS-2B cells having a greater slope than MESO-1 cells. However, the relative uptake value at the $\mathrm{IC}_{50}$ concentration of VGCF was approximately 2.1 in both types of cells. In the microscopy evaluation, the absolute amounts of intercellular VGCF seemed to be different, but the ratio of VGCF amount 

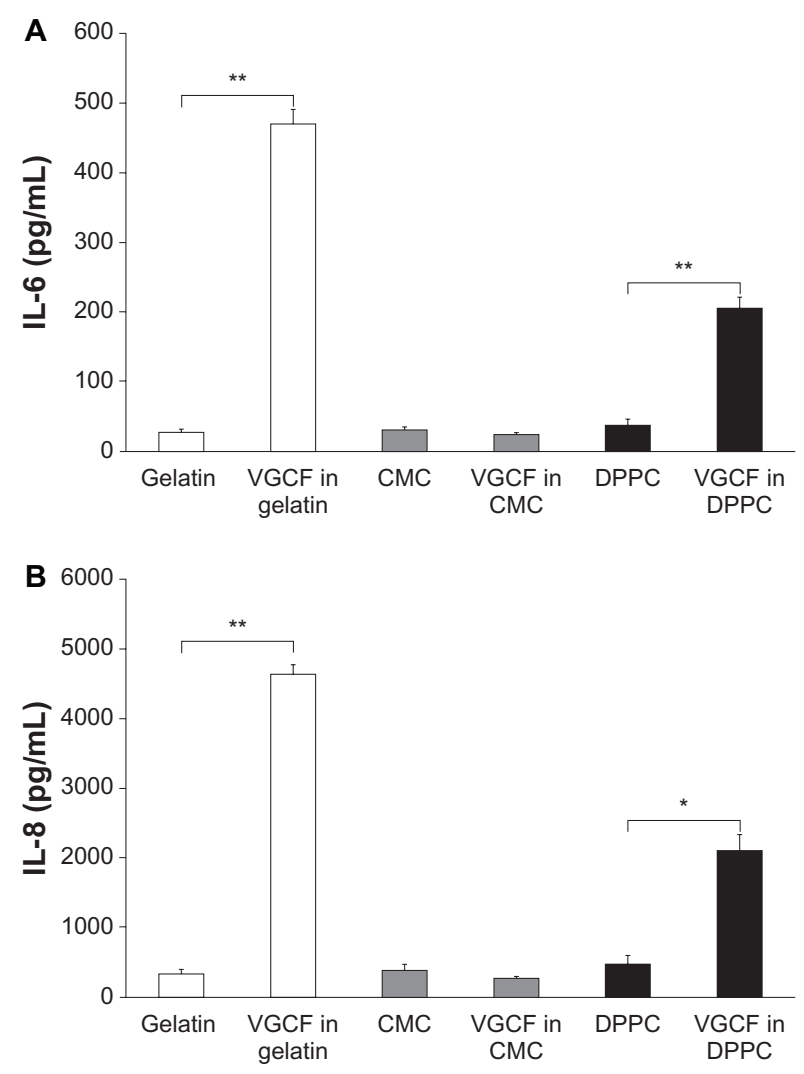

Figure 4 Quantification of cytokine secretion in different types of dispersion medium. Notes: Cytokine secretion in culture medium of BEAS-2B cells incubated with $10 \mu \mathrm{g} / \mathrm{mL}$ of VGCF in various dispersion media for 24 hours. Mean $\pm \mathrm{SE} n=3$, $* P<0.0$ I, $* * P<0.00$ I.

Abbreviations: CMC, carboxylmethyl cellulose; DPPC, I,2-dipalmitoylsn-glycero3-phosphocholine; SE, standard error; VGCF, vapor grown carbon fiber $\left(\mathrm{VGCF}^{\circledR}\right)$.

to cell volume was almost identical in the two cell types (Supplementary 7).

The mean diameters of the BEAS-2B and MESO-1 cells were found to be $15.8 \mu \mathrm{m}$ and $20.9 \mu \mathrm{m}$, respectively (Table 2). Their respective mean cell volumes were calculated to be $2,064 \mu^{3}$ and $4,847 \mu \mathrm{m}^{3}$.

\section{Discussion}

Because MWCNTs are hydrophobic, ${ }^{26,27}$ it is important to use dispersants when evaluating MWCNT safety. Therefore, we evaluated the influences of three different dispersants on the viability of cells exposed to a commercial MWCNT material. For dispersants, we selected gelatin and CMC, which are commonly used in pharmaceuticals and food products, as well as DPPC, which is used in experimental lung-exposure conditions. $^{21,28}$

Previous safety evaluations of CNTs have used direct suspensions in culture medium or commonly used dispersants (eg, Tween 80, dipalmitoyl lecithin, Arabic gum). ${ }^{29-32}$ However, the results of these evaluations were controversial and did not yield clear toxicological information regarding CNTs. It was initially thought that the differences in results were caused by the type of CNT (eg, single-walled versus multi-walled), the included impurities, or differences in cell lines, and little attention was paid to the type of dispersant. Recent reports have described the effects of dispersants on inhibiting the aggregation of CNTs; ${ }^{33-35}$ but the differences among the common dispersants are still unclear. No previous reports have compared the effects of different dispersants under the same conditions.

In the present study, we obtained contradictory results of increased and decreased cell viability with the same lot of CNTs and the same cell type; the only difference in experimental conditions was the type of dispersant. These results indicate the possibility that MWCNT safety evaluations are influenced by the type of dispersant. In general, dispersants are amphiphilic and exhibit hydrophilicity and hydrophobicity based on their inherent structure; they disperse hydrophobic substances. In all dispersants, VGCF was dispersed at similar levels after 1 hour, as seen by microscopic observation. At 24 hours, VGCF dispersed and CMC showed no change in agglomeration outside of the cells. By contrast, some of the VGCF dispersed with gelatin or DPPC agglomerated in the culture medium, and most of the single and agglomerated VGCF was internalized into the cells after 24 hours. Moreover, single VGCF fibers showed Brownian motion after 1 hour when dispersed with gelatin or CMC. These observations indicate that differences in dispersants might influence the in vitro response of cells to VGCF. Additionally, the VGCF suspended with PBS could not obtain sufficient suspension under these experimental conditions because of its light weight (results not shown). However, a small amount of agglomerated VGCF in PBS sank to the bottom of the culture dish and was endocytosed by the cells, leading us to surmise that VGCF has the surface characteristics needed for cellular uptake.

Noticeably, there was no distinctive change in the physical characteristics of VGCF dispersed in the three different dispersants, other than agglomerate diameter (Table 1). It has been reported that the zeta potential influences the cellular uptake and cytotoxicity of nanomaterials. ${ }^{36,37}$ However, those studies measured the zeta potential under different conditions from studies exposing the nanomaterials to cells. In our study, there was no difference in the zeta potential of VGCF dispersed with the three dispersants in culture medium. Moreover, there have been many reports that CNTs enter the cell, and the bioactivity of CNTs is well known. ${ }^{38}$ These facts indicate that other unknown factors, such as the relationship between CNT receptors on the cell membrane 


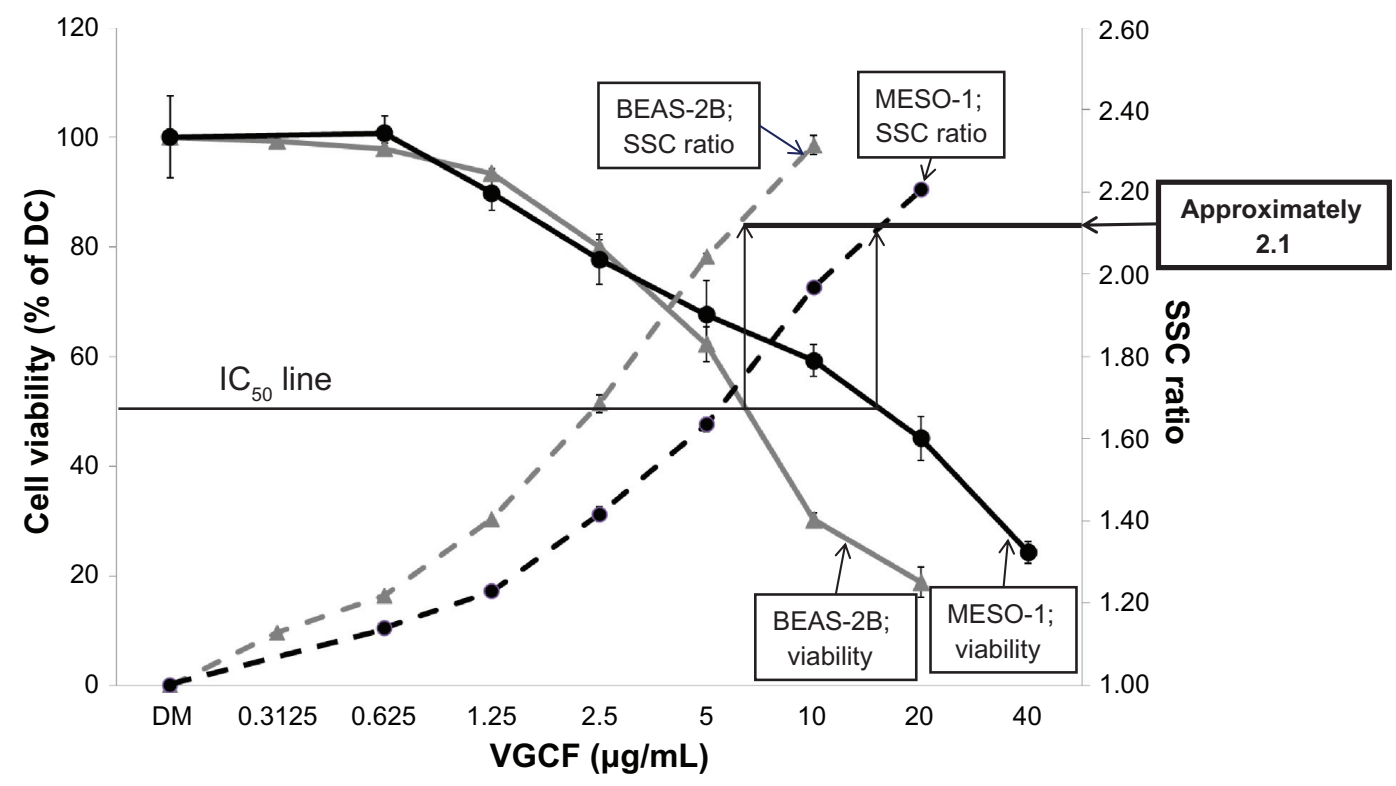

Figure 5 Dose-dependent curve of cell viability and VGCF uptake. Viability of BEAS-2B and MESO-I cells incubated with varying concentrations of VGCF in gelatin medium for 24 hours.

Notes: The data represent the relative ratio of the viability in DC with VGCF to the viability in DC without VGCF (mean \pm SE $n=8$, $* P<0.01$, $* * P<0.00$ I). SSC ratio of BEAS-2b and MESO-I cells incubated with varying concentrations of VGCF in gelatin for 24 hours. Each sample was 10,000 cells. Mean $\pm S E n=3$, $* P<0.01, * * P<0.001$.

Abbreviations: DC, dispersant control; SSC, side scatter; SE, standard error; VGCF, vapor grown carbon fiber $\left(\mathrm{VGCF}^{\circledR}\right)$.

and dispersants, also contribute to the rate of endocytosis. Therefore, dispersants, such as CMC, that inhibit cellular uptake are not suitable for safety assessments of VGCF. However, VGCF with CMC could avoid acute and severe toxicity because of its excellent dispersion. If the mechanism by which CMC suppresses VGCF uptake is clarified and found to apply to the surface-chemical modification of CNT, highly biocompatible CNTs may be developed. ${ }^{26,39,40}$ Recently, many reports have described possible medical applications for surface-modified CNTs. ${ }^{41,42}$

We also examined the effect of the dispersion medium on the immune response, which is an index of the critical biological responses to VGCF. SWCNTs have been reported to decrease the proliferation of human lung epithelium in vitro. ${ }^{19}$ However, the cells used in that report do not internalize SWCNTs. Another study reported that a cytokine assay could not provide accurate measurements because SWCNTs adsorbed cytokines. ${ }^{18}$ However, BEAS-2B cells that internalized VGCF in gelatin or in DPPC exhibited increased IL-6 and IL-8 secretion, whereas cytokine secretion was not altered when the VGCF in CMC were not internalized.

Table 2 Cell size

\begin{tabular}{ll}
\hline Cell line & Diameter $(\mu \mathrm{m})$ \\
\hline BEAS-2B & $15.8 \pm 2.6$ \\
MESO-I & $20.9 \pm 3.8$ \\
\hline
\end{tabular}

Cytokine secretion, which is an indicator of an inflammatory response, is increased in the bronchoalveolar lavage fluid of mice exposed to CNTs. ${ }^{43-45}$ Our results indicate that VGCF uptake is critical for cytokine secretion, which is consistent with other in vivo studies.

In the present study, the amount of VGCF uptake was represented as the relative ratio compared with the VGCF-free experimental condition. As a result, the uptake amounts of VGCF in gelatin were higher than those of VGCF in DPPC at 1 hour after VGCF exposure. At that time, the amounts of VGCF on the bottom of the culture dish were similar for all three dispersants.

The dispersant might also affect the uptake rate of VGCF into the cells. The intracellular amount of VGCF in gelatin was increased, compared with other dispersants; consequently, the intracellular VGCF inhibited cell proliferation and decreased cell viability to less than $50 \%$. The doubling times of BEAS-2B and MESO-1 cells are approximately 28 hours and 26 hours, respectively, and the cell count had almost doubled at the time of the alamarBlue ${ }^{\circledR}$ assay in this experiment. Thus, the cell viability of less than $50 \%$ represented the cytotoxic effect of VGCF. In the case of DPPC, we think that the cells were proliferating during VGCF uptake, and consequently, the concentration of VGCF per cell was reduced. Therefore, the cell viability was maintained at approximately $80 \%$ by VGCF in DPPC as a result of the relatively small VGCF uptake. In contrast, in the experiment with VGCF in gelatin and BEAS-2B cells, 
the uptake ratio at $80 \%$ cell viability was approximately 1.8 , which was similar to VGCF in DPPC. This result suggests that the cell viability of VGCF was related to the intracellular concentration of VGCF, not to the type of dispersant.

Moreover, the relationship between cell viability and cell differences might not be significant because the relative uptake ratio was approximately 2.1 at the $\mathrm{IC}_{50}$ of VGCF in both types of cells. However, in the microscopic images, it seemed that the absolute amount of intracellular VGCF differed between BEAS-2B cells and MESO-1 cells. The relative ratio of VGCF seemed to represent an absolute quantity of VGCF versus the intracellular capacity, because the SSC of flow cytometry represents the inner complexity of the cells based on the shape of the nucleus, the amount and type of cytoplasmic granules, or the membrane roughness. In fact, the cell volume of MESO-1 cells was about 2.3 times larger than that of BEAS-2B cells. This value was almost the same as that of the $\mathrm{IC}_{50}$ concentration.

We performed the AB assay and measured SSC simultaneously, under the same experimental conditions. When the starting cell density was changed, the SSC value and cell viability at one VGCF concentration was also altered, but the $\mathrm{SSC}$ value at $\mathrm{IC}_{50}$ was constant.

In conclusion, we found that the biological response to VGCF in vitro is influenced by the dispersant. The variety of dispersant affects the uptake rate and cell proliferation rate. In contrast, VGCF induced cytotoxicity and inflammatory reactions based on the intracellular concentration of VGCF, not based on cell differences. More detailed studies are needed to elucidate the exact biological mechanisms involved.

\section{Acknowledgments}

We thank the staff of the Division of Instrumental Analysis in the Research Center for Human and Environmental Sciences of Shinshu University for their help. This research was supported by the Program for Fostering Regional Innovation in Nagano and a Grant-in-Aid (Number 19002007) from the Ministry of Education, Culture, Sports, Science, and Technology of Japan.

\section{Disclosure}

The authors have no conflicts of interest to declare in this work.

\section{References}

1. Endo M, Strano MS, Ajayan PM. Potential applications of carbon nanotubes. Carbon Nanotubes. 2008;111:13-61.

2. Donaldson K, Aitken R, Tran L, et al. Carbon nanotubes: a review of their properties in relation to pulmonary toxicology and workplace safety. Toxicol Sci. 2006;92(1):5-22.
3. Muller J, Huaux F, Moreau N, et al. Respiratory toxicity of multi-wall carbon nanotubes. Toxicol Appl Pharmacol. 2005;207(3):221-231.

4. Shvedova AA, Kisin ER, Mercer R, et al. Unusual inflammatory and fibrogenic pulmonary responses to single-walled carbon nanotubes in mice. Am J Physiol Lung Cell Mol Physiol. 2005;289(5):L698-L708.

5. Takagi A, Hirose A, Nishimura T, et al. Induction of mesothelioma in p53+/- mouse by intraperitoneal application of multi-wall carbon nanotube. J Toxicol Sci. 2008;33(1):105-116.

6. Poland CA, Duffin R, Kinloch I, et al. Carbon nanotubes introduced into the abdominal cavity of mice show asbestos-like pathogenicity in a pilot study. Nat Nanotechnol. 2008;3(7):423-428.

7. Ellinger-Ziegelbauer H, Pauluhn J. Pulmonary toxicity of multi-walled carbon nanotubes (Baytubes) relative to alpha-quartz following a single $6 \mathrm{~h}$ inhalation exposure of rats and a 3 months post-exposure period. Toxicology. 2009;266(1-3):16-29.

8. Ma-Hock L, Treumann S, Strauss V, et al. Inhalation toxicity of multiwall carbon nanotubes in rats exposed for 3 months. Toxicol Sci. 2009; 112(2):468-481.

9. Pacurari M, Yin XJ, Zhao J, et al. Raw single-wall carbon nanotubes induce oxidative stress and activate MAPKs, AP-1, NF-kappaB, and Akt in normal and malignant human mesothelial cells. Environ Health Perspect. 2008;116(9):1211-1217.

10. Hirano S, Fujitani Y, Furuyama A, Kanno S. Uptake and cytotoxic effects of multi-walled carbon nanotubes in human bronchial epithelial cells. Toxicol Appl Pharmacol. 2010;249(1):8-15.

11. Monteiro-Riviere NA, Nemanich RJ, Inman AO, Wang YY, Riviere JE. Multi-walled carbon nanotube interactions with human epidermal keratinocytes. Toxicol Lett. 2005;155(3):377-384.

12. Jacobsen NR, Pojana G, White P, et al. Genotoxicity, cytotoxicity, and reactive oxygen species induced by single-walled carbon nanotubes and $\mathrm{C}(60)$ fullerenes in the FE1-Mutatrade markMouse lung epithelial cells. Environ Mol Mutagen. 2008;49(6):476-487.

13. Hirano S, Kanno S, Furuyama A. Multi-walled carbon nanotubes injure the plasma membrane of macrophages. Toxicol Appl Pharmacol. 2008; 232(2):244-251.

14. De Nicola M, Gattia D, Bellucci S, et al. Effect of different carbon nanotubes on cell viability and proliferation. $J$ Phys Condens Matter. 2007;19(39):395013.

15. Flahaut E, Durrieu MC, Remy-Zolghadri M, Bareille R, Baquey CH. Investigation of the cytotoxicity of CCVD carbon nanotubes towards human umbilical vein endothelial cells. Carbon. 2006;44(6):1093-1099.

16. Pulskamp K, Diabaté S, Krug HF. Carbon nanotubes show no sign of acute toxicity but induce intracellular reactive oxygen species in dependence on contaminants. Toxicol Lett. 2007;168(1):58-74.

17. Yang ST, Wang X, Jia G, et al. Long-term accumulation and low toxicity of single-walled carbon nanotubes in intravenously exposed mice. Toxicol Lett. 2008;181(3):182-189.

18. Davoren M, Herzog E, Casey A, et al. In vitro toxicity evaluation of single walled carbon nanotubes on human A549 lung cells. Toxicol In Vitro. 2007;21(3):438-448

19. Herzog E, Byrne HJ, Casey A, et al. SWCNT suppress inflammatory mediator responses in human lung epithelium in vitro. Toxicol Appl Pharmacol. 2009;234(3):378-390.

20. Kim JS, Song KS, Lee JH, Yu IJ. Evaluation of biocompatible dispersants for carbon nanotube toxicity tests. Arch Toxicol. 2011. Epub 2011 Jun 9.

21. Porter D, Sriram K, Wolfarth M, et al. A biocompatible medium for nanoparticle dispersion. Nanotoxicology. 2008;2(3):144-154.

22. Endo M, Kim Y, Hayashi T, et al. Vapor-grown carbon fibers (VGCFs): Basic properties and their battery applications. Carbon. 2001;39(9): 1287-1297.

23. Kim Y, Hayashi T, Endo M, et al. Synthesis and structural characterization of thin multi-walled carbon nanotubes with a partially facetted cross section by a floating reactant method. Carbon. 2005;43(11):2243-2250.

24. Usami N, Fukui T, Kondo M, et al. Establishment and characterization of four malignant pleural mesothelioma cell lines from Japanese patients. Cancer Sci. 2006;97(5):387-394. 
25. Al-Jamal KT, Kostarelos K. Assessment of cellular uptake and cytotoxicity of carbon nanotubes using flow cytometry. Methods $\mathrm{Mol}$ Biol. 2010;625:123-134.

26. Antonelli A, Serafini S, Menotta M, et al. Improved cellular uptake of functionalized single-walled carbon nanotubes. Nanotechnology. 2010; 21(42):425101.

27. Chen RJ, Bangsaruntip S, Drouvalakis KA, et al. Noncovalent functionalization of carbon nanotubes for highly specific electronic biosensors. Proc Natl Acad Sci U S A. 2003;100(9):4984-4989.

28. Foucaud L, Wilson MR, Brown DM, Stone V. Measurement of reactive species production by nanoparticles prepared in biologically relevant media. Toxicol Lett. 2007;174(1-3):1-9.

29. Hurt RH, Monthioux M, Kane A. Toxicology of carbon nanomaterials: status, trends, and perspectives on the special issue. Carbon. 2006;44(6): 1028-1033.

30. Lindberg HK, Falck GC, Suhonen S, et al. Genotoxicity of nanomaterials: DNA damage and micronuclei induced by carbon nanotubes and graphite nanofibres in human bronchial epithelial cells in vitro. Toxicol Lett. 2009;186(3):166-173.

31. Simon-Deckers A, Gouget B, Mayne-L'hermite M, Herlin-Boime N, Reynaud C, Carriere M. In vitro investigation of oxide nanoparticle and carbon nanotube toxicity and intracellular accumulation in A549 human pneumocytes. Toxicology. 2008;253(1-3):137-146.

32. Tabet L, Bussy C, Amara N, et al. Adverse effects of industrial multiwalled carbon nanotubes on human pulmonary cells. J Toxicol Environ Health A. 2009;72(2):60-73.

33. Herzog E, Byrne HJ, Davoren M, Casey A, Duschl A, Oostingh GJ. Dispersion medium modulates oxidative stress response of human lung epithelial cells upon exposure to carbon nanomaterial samples. Toxicol Appl Pharmacol. 2009;236(3):276-281.

34. Porter DW, Hubbs AF, Mercer RR, et al. Mouse pulmonary dose- and time course-responses induced by exposure to multi-walled carbon nanotubes. Toxicology. 2010;269(2-3):136-147.

35. Wako K, Kotani Y, Hirose A, Doi T, Hamada S. Effects of preparation methods for multi-wall carbon nanotube (MWCNT) suspensions on MWCNT induced rat pulmonary toxicity. J Toxicol Sci. 2010;35(4): 437-446.
36. Petushkov A, Intra J, Graham JB, Larsen SC, Salem AK. Effect of crystal size and surface functionalization on the cytotoxicity of silicalite-1 nanoparticles. Chem Res Toxicol. 2009;22(7):1359-1368.

37. Slowing I, Trewyn BG, Lin VS. Effect of surface functionalization of MCM-41-type mesoporous silica nanoparticles on the endocytosis by human cancer cells. J Am Chem Soc. 2006;128(46):14792-14793.

38. Raffa V, Ciofani G, Vittorio O, Riggio C, Cuschieri A. Physicochemical properties affecting cellular uptake of carbon nanotubes. Nanomedicine (Lond). 2010;5(1):89-97.

39. Dong L, Witkowski CM, Craig MM, Greenwade MM, Joseph KL. Cytotoxicity effects of different surfactant molecules conjugated to carbon nanotubes on human astrocytoma cells. Nanoscale Res Lett. 2009;4(12):1517-1523.

40. Firme CP 3rd, Bandaru PR. Toxicity issues in the application of carbon nanotubes to biological systems. Nanomedicine. 2010;6(2):245-256.

41. Li X, Fan Y, Watari F. Current investigations into carbon nanotubes for biomedical application. Biomed Mater. 2010;5(2):22001.

42. Liang F, Chen B. A review on biomedical applications of single-walled carbon nanotubes. Curr Med Chem. 2010;17(1):10-24.

43. Inoue $\mathrm{K}$, Koike E, Yanagisawa R, Hirano S, Nishikawa M, Takano H. Effects of multi-walled carbon nanotubes on a murine allergic airway inflammation model. Toxicol Appl Pharmacol. 2009;237(3): 306-316.

44. Shvedova AA, Fabisiak JP, Kisin ER, et al. Sequential exposure to carbon nanotubes and bacteria enhances pulmonary inflammation and infectivity. Am J Respir Cell Mol Biol. 2008;38(5):579-590.

45. Shvedova AA, Kisin E, Murray AR, et al. Inhalation vs aspiration of single-walled carbon nanotubes in C57BL/6 mice: inflammation, fibrosis, oxidative stress, and mutagenesis. Am J Physiol Lung Cell Mol Physiol. 2008;295(4):L552-L565.

46. Guo L, Von Dem Bussche A, Buechner M, Yan A, Kane AB, Hurt RH. Adsorption of essential micronutrients by carbon nanotubes and the implications for nanotoxicity testing. Small. 2008;4(6):721-727. 


\section{Supplementary materials}

Scanning electron microscopy (SEM, JEOL JSM-6335Fs) observation was used to measure the diameter and length of MWCNTs, whereas X-ray powder diffraction measurement (JEOL-JDX3532, $\mathrm{CuK}_{\alpha}, \lambda=1.54056 \AA$ ) was carried out to obtain the interlayer spacing by using the Scherrer equation and the X-ray pattern. On the basis of Raman spectra taken with a 532-nm laser line (a Kaiser HoloLab 5000 system), the R value $\left(I_{D} / I_{G}\right)$ was calculated from the integrated intensity of the D-band divided by the intensity of the G-band. The specific surface area of the MWCNT sample was measured by determining nitrogen adsorption at $77 \mathrm{~K}$ (ASAP2020, Micromeritics, USA). The real density of the sample was measured by using a gas pycnometer (Accupyc 1330, Shimazu). The zeta potential and particle size were recorded on a NICOMP 380ZLS (Particle Sizing Systems, USA). The particle-size measurement was performed by using a dynamic light scattering (DLS) technique that is sensitive to the presence of agglomerate particles, and the zeta potentials were measured by employing a phase-shift analysis for electrophoretic light scattering.

Figure SI Analytical methods for vapor grown carbon fiber $\left(\right.$ VGCF $\left.^{\circledR}\right)$ properties in Table I.
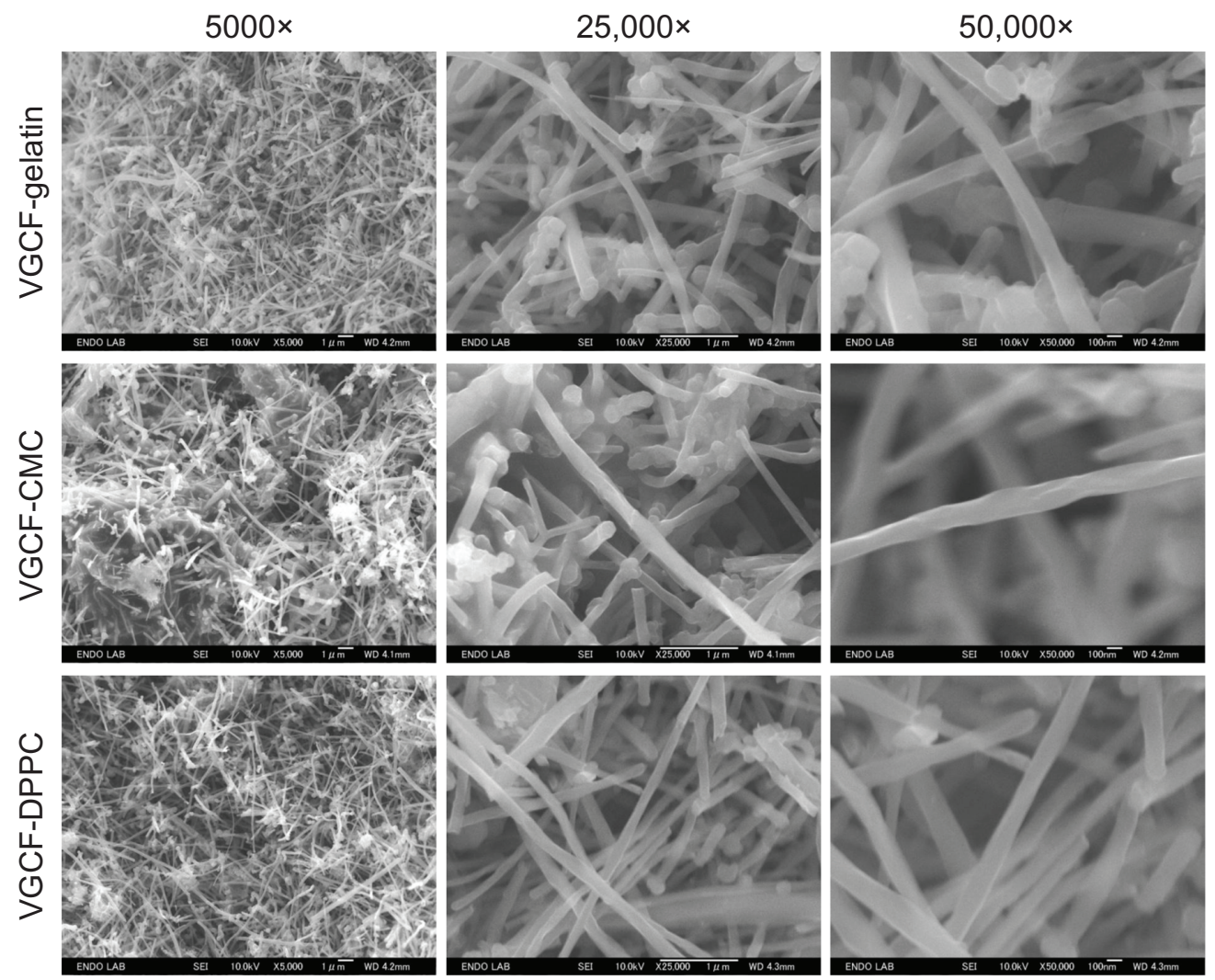

Figure S2 Field emission-scanning electron microscopy image of vapor grown carbon fiber (VGCF ${ }^{\circledR}$ in different dispersants.

Abbreviations: CMC, carboxylmethyl cellulose; DPPC, I,2-dipalmitoylsn-glycero-3-phosphocholine. 


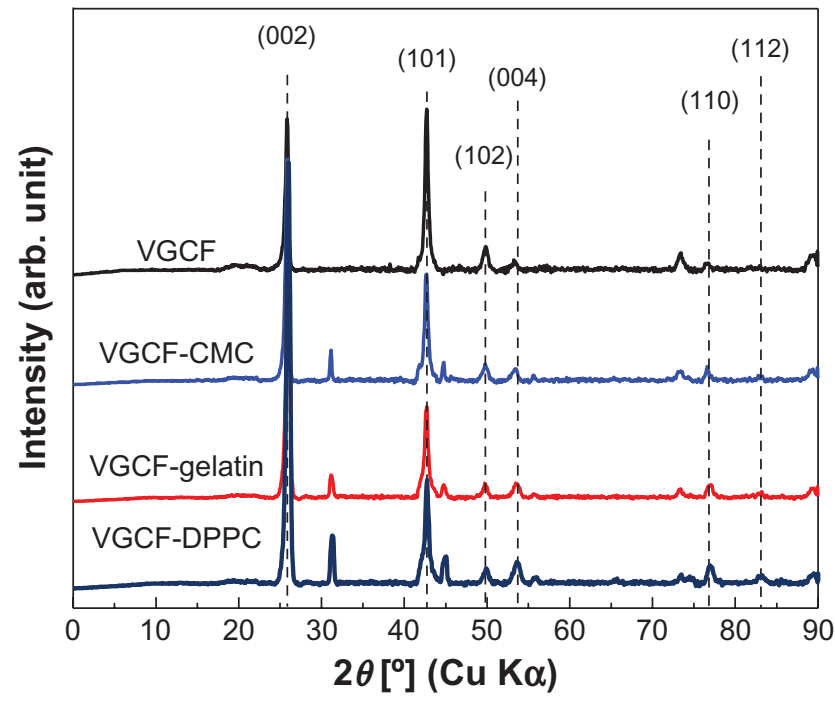

Figure S3 X-ray diffraction data for vapor grown carbon fiber $\left(\mathrm{VGCF}^{\circledR}\right)$ in different dispersants.

Abbreviations: CMC, carboxylmethyl cellulose; DPPC, I,2-dipalmitoylsn-glycero3-phosphocholine.

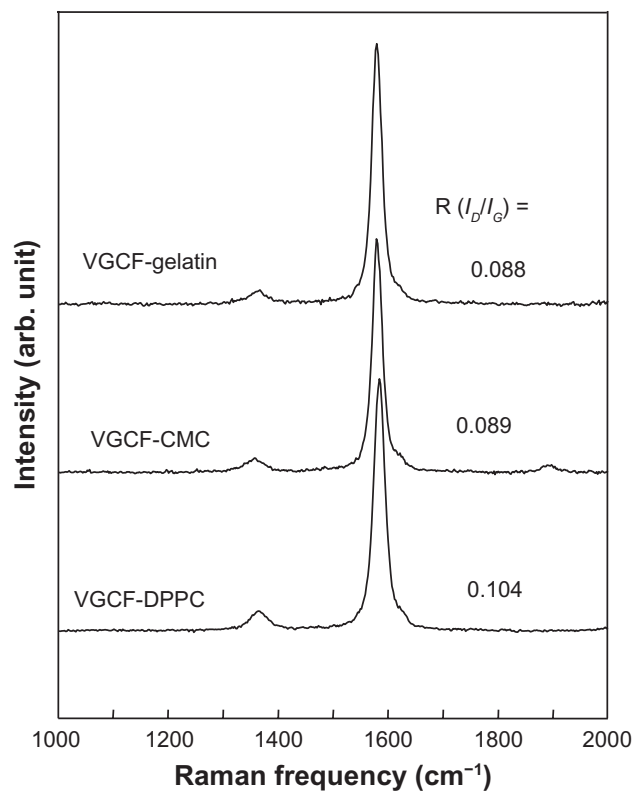

Figure S4 Raman spectroscopy of vapor grown carbon fiber $\left(\mathrm{VGCF}^{\circledR}\right)$ in different dispersants.

Abbreviations: CMC, carboxylmethyl cellulose; DPPC, I,2-dipalmitoylsn-glycero3-phosphocholine.

\begin{tabular}{|c|c|c|c|}
\hline Sample & Solution ID & Z-potential (mV) & Mean Z-potential \pm Dev. $(\mathrm{mV})$ \\
\hline \multirow[t]{3}{*}{ VGCF in gelatin sol } & Gelatin1 & 0.41 & \multirow{3}{*}{$1.18 \pm 1.66$} \\
\hline & Gelatin2 & 0.04 & \\
\hline & Gelatin3 & 3.09 & \\
\hline \multirow[t]{3}{*}{ VGCF in CMC sol } & CMC1 & 0.30 & \multirow{3}{*}{$1.22 \pm 1.72$} \\
\hline & $\mathrm{CMC} 2$ & 0.16 & \\
\hline & CMC3 & 3.20 & \\
\hline \multirow[t]{3}{*}{ VGCF in DPPC sol } & DPPC1 & 0.88 & \multirow{3}{*}{$1.09 \pm 0.22$} \\
\hline & DPPC2 & 1.68 & \\
\hline & DPPC3 & 0.71 & \\
\hline
\end{tabular}

Figure S5 Zeta potential of vapor grown carbon fiber $\left(\mathrm{VGCF}^{\circledR}\right)$ suspensions in three different dispersants.

Abbreviations: CMC, carboxylmethyl cellulose; DPPC, I,2-dipalmitoylsn-glycero-3-phosphocholine; Dev., deviation; sol, solution. 

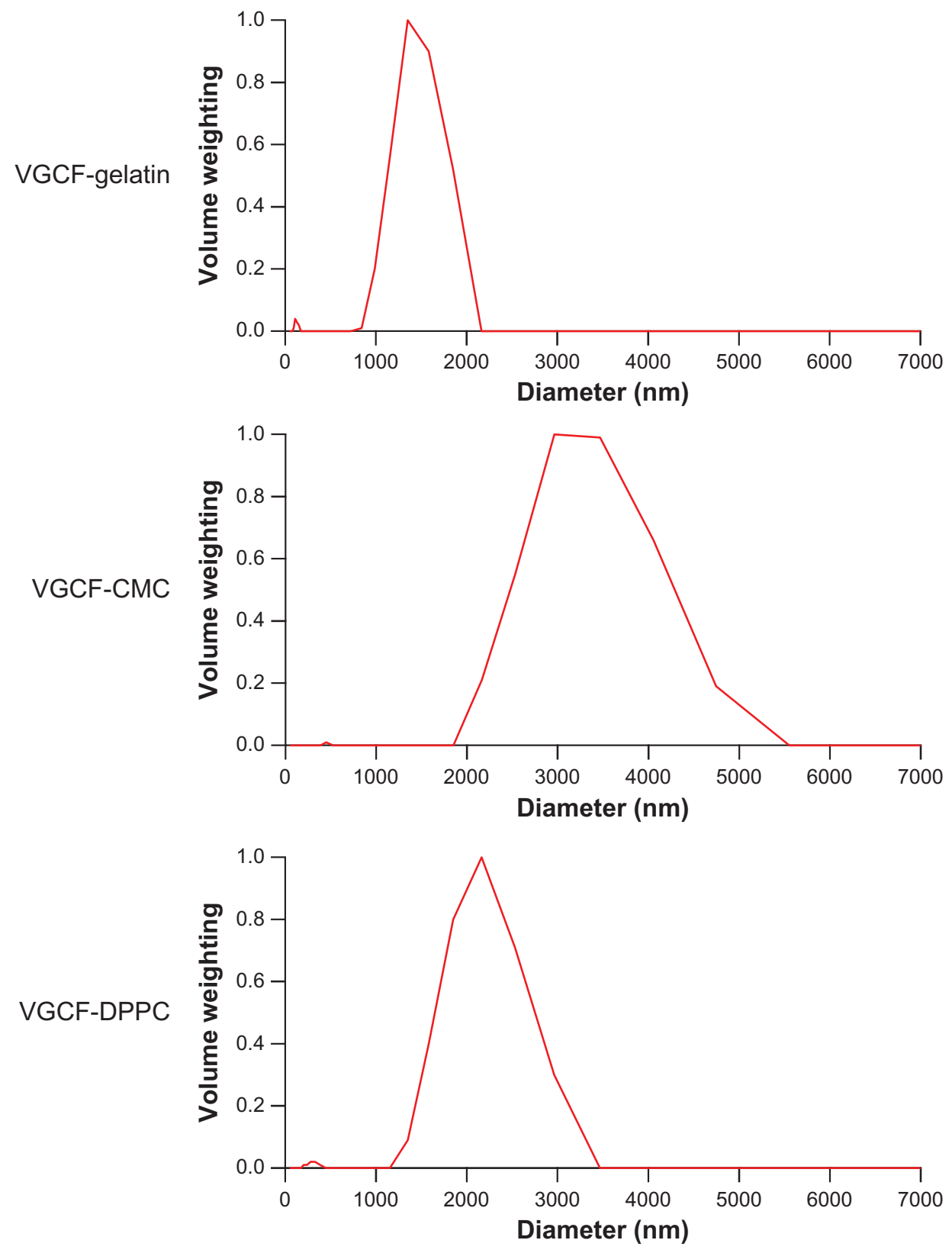

Figure S6 Agglomerate diameter of vapor grown carbon fiber $\left(\mathrm{VGCF}^{\circledR}\right)$ suspending in three different dispersants. Abbreviations: CMC, carboxylmethyl cellulose; DPPC, I,2-dipalmitoylsn-glycero-3-phosphocholine.
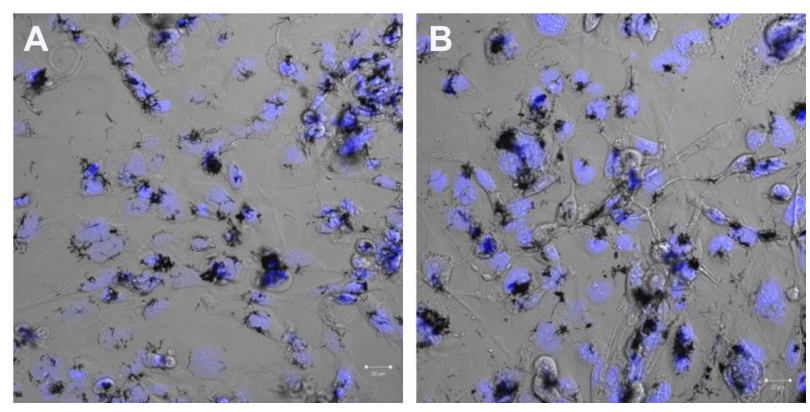

Figure S7 Images of cells exposed to vapor grown carbon fiber $\left(\mathrm{VGCF}^{\circledR}\right)$ at the approximate concentration of $\mathrm{IC}_{50}$ for 24 hours. (A) BEAS-2B cells exposed to $5 \mu \mathrm{g} / \mathrm{mL}$ of VGCF and (B) MESO-I cells exposed to $10 \mu \mathrm{g} / \mathrm{mL}$ of VGCF.
Movie SI Movie of BEAS-2B cells incubated with $10 \mu \mathrm{g} / \mathrm{mL}$ of vapor grown carbon fiber $\left(\mathrm{VGCF}^{\circledR}\right)$ in gelatin for I hour. Available here.

Notes: Microscope was set for bright-field mode and magnified $\times 200$. The images were recorded for 10 seconds.

Movie S2 Movie of BEAS-2B cells incubated with $10 \mu \mathrm{g} / \mathrm{mL}$ of VGCF in CMC for I hour. Available here.

Notes: Microscope was set for bright-field mode and magnified $\times 200$. The images were recorded for 10 seconds.

Abbreviations: CMC, carboxylmethyl cellulose; VGCF, vapor grown carbon fiber $\left(\mathrm{VGCF}^{\circledR}\right)$.

Movie S3 Movie of BEAS-2B cells incubated with $10 \mu \mathrm{g} / \mathrm{mL}$ of VGCF in DPPC for I hour. Available here.

Notes: Microscope was set for bright-field mode and magnified $\times 200$. The images were recorded for 10 seconds.

Abbreviations: DPPC, I,2-dipalmitoyl-sn-glycero-3-phosphocholine; VGCF, vapor grown carbon fiber $\left(\mathrm{VGCF}^{\circledR}\right)$. 
Movie S4 Movie of BEAS-2B cells incubated with $10 \mu \mathrm{g} / \mathrm{mL}$ of VGCF in CMC for 24 hours. Available here.

Notes: Microscope was set for bright-field mode and magnified $\times 200$. The images were recorded for 10 seconds.

Abbreviations: CMC, carboxylmethyl cellulose; VGCF, vapor grown carbon fiber $\left(\mathrm{VGCF}^{\circledR}\right)$.

\section{Publish your work in this journal}

The International Journal of Nanomedicine is an international, peerreviewed journal focusing on the application of nanotechnology in diagnostics, therapeutics, and drug delivery systems throughou the biomedical field. This journal is indexed on PubMed Central, MedLine, CAS, SciSearch $®$, Current Contents $® /$ Clinical Medicine,
Journal Citation Reports/Science Edition, EMBase, Scopus and the Elsevier Bibliographic databases. The manuscript management system is completely online and includes a very quick and fair peer-review system, which is all easy to use. Visit http://www.dovepress.com/ testimonials.php to read real quotes from published authors.

Submit your manuscript here: http://www.dovepress.com/international-journal-of-nanomedicine-journal 